\title{
Hollybush Academy: A Case Study In Selected Not-For-Profit Accounting Issues
}

Frank J. Grippo, William Paterson University, USA

Sia Nassiripour, William Paterson University, USA

\begin{abstract}
The purpose of this case is to help students explore accounting issues often confronted by auditors of not-for-profit organizations. Given certain facts, the goal of the case is to require students to analyze the footnotes prepared by the auditors and discuss the presentation, classification and valuation of items not reflected on the financial statements prepared by the client. The case is intended for students who are taking an advanced accounting or not-for-profit accounting course.
\end{abstract}

\section{INTRODUCTION}

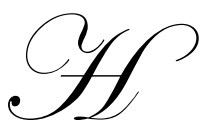

ollybush Academy is a private coed religious college preparatory high school located on a 78 acre property in Windy Hills, New York, a wealthy suburb north of New York City. It is affiliated with one of the Protestant churches and is an educational corporation established under a certificate of incorporation issued by the State of New York in 1925. It has an approximate enrollment of 210 students and is supported by tuition and related fees, contributions, and income from endowment investments. The annual tuition, excluding fees, is $\$ 26,000$ per year.

The school has a history of high academic standards and consistently has gotten its graduates into the finest colleges and universities in the country, including sending a number of students to Ivy League universities each year. Its alumni are very successful and many have achieved recognition in medicine, law, investment banking, accounting, and sundry other professions. Its alumni include prominent college professors, judges, partners in CPA and law firms, famous surgeons, and TV personalities. Moreover, the alumni are very involved in the school's activities and are very appreciative of the education they received. Accordingly, they give back handsomely to the school.

\section{$\underline{\text { Present Situation }}$}

Since the school has never had the need to be audited as they had no existing bank loans, had no Form 990 (annual report for non profit organizations) requirements (religious organizations are exempt from filling Form 990), quarterly and annual financial statements were prepared by the Chief Fiscal Officer. For years, the Board of Trustees operated as a "rubber stamp" board and merely reviewed the financial statements, approved the budget for the following year, and made a number of minor recommendations.

Having served the school for 25 years as President, Mrs. Joyce Reynolds recently retired. At the same time, several new members were appointed to the Board of Trustees. These new Board members had a more business like approach, and accordingly, insisted on conducting an extensive search for a replacement. Their goal was to hire someone with a keen understanding of current trends in education and who possessed the ability to further implement technology into the classroom. In addition, at the same time the Board members started to ask probing accounting and finance questions and thus came to the conclusion that the present Chief Fiscal Officer did not provide satisfactory answers to their questions and was unable to furnish schedules and information requested by them. Consequently, the Board redefined the duties of the Chief Fiscal Officer and decided to conduct a search for a 
Vice-President of Finance. The chief fiscal officer did not object to downgrading her position and actually appeared to welcome being the second in charge. Although the net expense would be much higher, the Board was insistent on doing things in a more business like manner. Since the chief fiscal officer's assistant in the accounting department, who handled many of the general bookkeeping duties, was leaving as her husband was being transferred to Ashville, North Carolina, the moves proposed by the Board were not as costly as the assistant was not replaced.

After a number of interviews, a president (Dr. Robert Stevenson) was hired. He had extensive experience in both education and business. He received his Ed.D degree from a prominent university in New York City and then pursued an MBA. He taught high school and worked for a Fortune 500 company. However, his first love was education. His desire was to get into supervision where he could use his knowledge of both education and business. The Board was able to lure him away from his comfortable job as principal at a very prestigious prep school in New York City.

At the same time, the Board was able to hire an outstanding person at a very reasonable price as Vice President of Finance. Ms. Susan Kennedy was formerly a CFO of a hedge fund. She has her CPA certificate and made enough money (a fortune by many people's standards) to be comfortable for the rest of her life. Being only 45 years old, her desire was to work for a not-for-profit organization and "give back", if you will, to society. She wanted to work for a place where she could add value. Hollybush Academy was a perfect place for her. Besides, she was more than satisfied with her $\$ 100,000$ salary as money was not a factor.

The new Board's business approach to the school resulted in a number of reforms. Working closely with the new President and Vice President of Finance, they established several committees including ones for Finance, Investment and Plant activities. Being concerned with corporate failures, such as WorldCom and Enron, and bank failures, such as Countrywide Bank and Bear Sterns due to the subprime mortgage fiasco, they became concerned with the potential for misstatements in the financial statements and the possibility of fraud. They were aware that the Sarbanes Oxley Act did not apply to them (being a nonpublic company and a not-for-profit organization). However, they wished to act as if it did. Therefore, they established a mandate that the financial statements should be audited and that the auditors should issue a management letter to detail any suggestions for improvements in internal controls, if any.

Requests for proposals were sent out to several CPA firms who concentrate on not-for-profit organizations. The firm of Arthur Novak \& Company from New York City was selected. After interviewing a number of firms, the Finance Committee recommended AN\&Co as auditors due to their extensive experience with not-for-profit organizations, particularly schools and religious organizations.

AN\&Co commenced their audit for the year ended June 30, 2007 on August 1, 2007. They obtained the school's trial balance as of June 30, 2006 since it was necessary to satisfy themselves to the Statement of Activities (asset, liability and net asset numbers as of the beginning of the year). In addition, they obtained the trial balance as of June 30, 2007, along with the financial statements prepared by the school. These statements were prepared by the Chief Financial Officer as the new President and Vice President were not scheduled to begin their jobs until September 1, 2007.

\section{Findings by Auditors}

The school's major assets are cash and cash equivalents, promises to give receivables, investment securities, bequests receivable, and premises and equipment. Its major liabilities are accounts payable, accrued expenses, accrued severance benefits, and deferred income. However, the accounting by the school in several of these areas was deficient in that current pronouncements (Financial Accounting Standards, particularly FAS \#116, \#117 and \#157) were not followed. Although the bookkeeping was accurate, the accounting was misleading and not in accordance with generally accepted accounting principles established in the United States. 


\section{Work by Auditors}

The auditors reviewed the trial balances as of June 30, 2006 and June 30, 2007, and noted that the comparative financial statement (Exhibit A) was prepared by the Chief Fiscal Officer from the respective trial balances.

During the engagement, the auditors found that the bookkeeping was generally accurate, but there were many financial reporting deficiencies. After much reconstruction of the accounting, the auditors were able to draft financial statements for the year ended June 30, 2007. The footnotes attached to the financial statements are below:

\section{Organization}

Hollybush Academy is a private coed religious college preparatory high school located in Windy Hills, New York, a wealthy suburb north of New York City. It is affiliated with one of the Protestant churches and is an educational corporation established under a certificate of incorporation issued by the State of New York in 1925. It has an approximate enrollment of 210 students and is supported by tuition and related fees, contributions, and income from endowment investments.

\section{Summary of Significant Accounting Policies}

\section{- Basis of Accounting and Use of Estimates}

The accompanying financial statements are prepared on the accrual basis of accounting. The preparation of these financial statements requires management to make estimates and assumptions that affect the reported amounts of assets and liabilities and disclosure of contingent assets and liabilities at the date of the financial statements and reported amounts of revenues and expenses during the reporting period. Actual amounts could differ from these estimates.

\section{- Basis of Presentation}

The school follows established standards for external financial reporting by not-for-profit organizations. Accounting standards require that unconditional promises to give be recorded as receivables and revenues and require the organization to distinguish between contributions received for each net asset category in accordance with donor imposed restrictions. Conditional promises to give are recognized when the conditions on which they depend are substantially met. The three net asset categories are unrestricted net assets, temporarily restricted net assets and permanently restricted net assets. Unrestricted net assets have no donor-imposed restrictions. Temporarily restricted net assets have donor-imposed restrictions that are satisfied either by the passage of time or expenditures that meet the donor-specified purpose. Permanently restricted net assets have donor-imposed restrictions that do not expire.

\section{- Federal Income Taxes}

The school is exempt from taxes pursuant to Section 501(c)(3) of the Internal Revenue Code as an educational, charitable and religious entity. Accordingly, no provision for income taxes has been recorded in the statement of activities and changes in net assets.

\section{- Expiration of Donor-Imposed Restrictions}

The expiration of a donor-imposed restriction on a contribution or on endowment income is recognized in the period in which the restriction expires and at that time the related resources are reclassified to unrestricted net assets. A restriction expires when the stipulated time has elapsed, when the stipulated purpose for which the resource was restricted has been fulfilled, or both. In addition, the school follows the policy of reporting donor-imposed restricted contributions and endowment income whose restrictions are met within the same fiscal year as unrestricted support.

\section{- Cash and Cash Equivalents}

The school considers all highly liquid investments with a maturity of three months or less when purchased to be cash equivalents. 


\section{- Concentration of Credit Risk}

The school maintains its regular and restricted cash balances and certificates of deposit with one highly respected financial institution. However, these deposits at times exceed the Federal Deposit Insurance Corporation (FDIC) insurance limit of $\$ 100,000$ per institution. As of June 30, 2007, the school's balances on deposit with this financial institution were $\$ 600,000$ in excess of the FDIC insurance limits.

Concentration of credit risk associated with investment securities is considered low due to the credit quality of the financial institution holding these investments.

\section{- Accounts and Promises to Give Receivable}

The school provides allowances for doubtful receivables equal to the estimated collection losses that will be incurred in collection of all receivables. The estimated losses are based on historical collection experience coupled with a review of the current status of the existing receivables, including promises to give.

\section{- Investment Securities}

Investment securities are recorded at fair value. The fair value of equity and debt securities is based on the quoted market value of the underlying securities. Gains and losses are realized as of the trade date for investments.

\section{- Premises and Equipment}

Acquisition of land, buildings, improvements, and equipment are stated at cost, or at the fair value at date of contribution if acquired by gift. Donated services related to the school's construction projects are capitalized at the fair value of such services. Depreciation expense has been computed using the straightline method. Estimated useful lives of the school's premises and equipment are as follows:

$\begin{array}{lc} & \text { Years } \\ \text { Building and building improvements } & 30 \\ \text { Furniture and equipment } & 3-7\end{array}$

\section{- Revenue Recognition}

The school records tuition and related fees as services are rendered through the academic year. Payments received in advance prior to June 30 which relate to the subsequent year are included in deferred income and other liabilities in the accompanying statement of financial position.

\section{- Advertising Costs}

Advertising costs are expensed as incurred and amounted to \$13,400 for the year ended June 30, 2007.

\section{- Volunteers}

A number of volunteers have made significant contributions of time to the school's program and support functions. The value of this contributed time does not meet the criteria for recognition of contributed services and accordingly, is not reflected in the accompanying financial statements.

\section{Promises to Give Receivable}

These amounts, less an appropriate allowance for uncollectible promises, are recorded at their estimated fair value with amounts due later than one year at the present value of estimated future cash flows. Promises to give receivable at June 30, 2007 are as follows: 
Promises to Give Receivable expected to be collected in--

Less than one year

One to five years

Thereafter

Less - allowance for uncollectible promises to give

Less - discount at $5 \%$

Net Promises to Give

\begin{tabular}{cr}
$\$$ & 837,400 \\
$3,000,000$ \\
$2,750,000$ \\
\hline & $6,587,400$ \\
& $(250,000)$ \\
& $(1,277,000)$ \\
\hline$\$ \quad 5,060,400$ \\
\hline \hline
\end{tabular}

4. Investment Securities

An analysis of the school's investment securities by fund at June 30, 2007 is as follows:

\begin{tabular}{|c|c|c|c|c|c|c|}
\hline \multirow{4}{*}{$\begin{array}{l}\text { Mutual Funds } \\
\text { Equities }\end{array}$} & \multicolumn{2}{|c|}{ Fair Value } & \multicolumn{2}{|r|}{ Cost } & \multicolumn{2}{|c|}{$\begin{array}{c}\text { Fair Value Over } \\
\text { (Under) Cost }\end{array}$} \\
\hline & $\$$ & $18,862,600$ & $\$$ & $16,522,400$ & $\$$ & $2,340,200$ \\
\hline & & $7,996,200$ & & $5,699,700$ & & $2,296,500$ \\
\hline & $\$$ & $26,858,800$ & $\$$ & $22,222,100$ & $\$$ & $4,636,700$ \\
\hline
\end{tabular}

An analysis of investment return for the year ended June 30, 2007 is as follows:

Interest and dividends

Realized gains

Unrealized gains

\begin{tabular}{rr}
$\$ \quad 723,300$ \\
250,800 \\
$3,066,500$ \\
\hline$\$ \quad 4,040,600$ \\
\hline
\end{tabular}

\section{Beneficial Interest in Charitable Trusts}

The school is the irrevocable beneficiary of two charitable trusts that are subject to certain split-interest agreements. At June 30, 2007, the school had an asset of $\$ 336,000$, respectively, for its beneficial interest in these trusts which has been calculated on a present value basis using a 5\% discount rate and the estimated mortality of the applicable donors.

\section{Bequests Receivable}

The school has been named as a beneficiary under the wills of two deceased alumni. Collection on the proceeds of these bequests is proceeding subsequent to the balance sheet date. Bequests receivable in the amount of $\$ 6,200,000$ have been recorded based on the available information from estate administrators.

\section{7. $\quad$ Premises and Equipment}

An analysis of premises and equipment as of June 30, 2007 is as follows:

Land

Building and building improvements

Furniture and equipment

Less--accumulated depreciation

Total

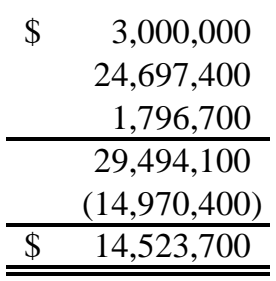

$\$ 3,000,000$

$24,697,400$

$\frac{1,796,700}{29,494,100}$

$\frac{(14,970,400)}{14,523,700}$

$\$ \quad 14,523,700$

\section{Accrued Severance Benefits}

During 2007, the school entered into severance agreements with seven faculty members. Accordingly, the school has agreed to pay these individuals a percentage of their regular salary in addition to providing medical coverage until the age of 65 . 
Severance benefits expected to be paid in --

\begin{tabular}{|c|c|c|}
\hline Less than one year & $\$$ & 324,300 \\
\hline One to two years & & 270,000 \\
\hline & & $\begin{array}{c}594,300 \\
(12,900)\end{array}$ \\
\hline Int Payable & $\$$ & 581,400 \\
\hline
\end{tabular}

\section{Contingencies}

From time to time, the school may become involved in legal claims arising in the ordinary course of its activities. In the opinion of management, the outcome of any legal proceedings are covered by the school's insurance policies and accordingly, would not have a material effect on its financial position or results of operations.

\section{Other Audit Findings}

- Review of tuition receivable at June 30, 2007 revealed that the provision for uncollectible tuition should be approximately $\$ 63,000$. The school has been employing the direct write off method when accounting for bad debts.

- Promises to give receivable relate to a capital campaign, the purpose of which was to raise money for scholarships so that more financial aid could be given to promising students in addition to providing resources for building improvements, particularly technology upgrades.

- Inventories relate to auxiliary services (bookstore and cafeteria). The school never took an actual count of the textbooks, clothing and supplies in the bookstore or of the non perishable cafeteria supplies at year end. They merely estimated the amount based on the relationship between bookstore purchases and sales and cafeteria purchases and sales.

- The school has a rather large endowment fund (Investment Securities) resulting from a number of major gifts from prominent alumni in addition to transfers each year of a portion of the excess of revenues over expenses. The school has been recording this amount at cost of the investments.

- Beneficial interest in charitable trusts relate to two trusts set up by an alumnus from the class of 1951 and another from the class of 1939. The beneficial interest in these trusts at June 30, 2007 was $\$ 336,000$. At June 30, 2006, the beneficial interest was $\$ 243,000$.

- Teachers work 10 months (September to June), but are paid over 12 months. At June 30, 2007, salaries applicable to July and August, 2007 amounted to approximately $\$ 420,000$. The corresponding amount for July and August, 2006 amounted to $\$ 404,000$.

- The school offered a severance package to teachers in order to provide an incentive to get a number of teachers to retire. Seven of the faculty members took advantage of the school's offer.

- Prior to June 30, 2007, the school collected $\$ 490,000$ relating to tuition for the following school year. The corresponding amount for the year ended June 30, 2006 was $\$ 380,000$. The school recorded the tuition as revenues when received.

- The net assets of the school were segregated into three funds, namely operating, plant and endowment funds. 
$\underline{\text { Instructions }}$

Review Statements of Financial Standards \#116, (Accounting for Contributions Received and Contributions Made), \#117 (Financial Statement Format), \#157 (Fair Value Measurement), and the AICPA Audit and Accounting Guide (Not-for-Profit Organizations). Note that FAS \#157 was effective for years ending after November 15, 2007; however, it was decided to apply early adoption of this pronouncement. Accordingly, analyze the auditors' footnotes and additional information provided and answer the following:

What account descriptions specifically would appear in the June 30, 2007 statements? How would these accounts be classified and valued? Cite references to SFAS \#116, \#117, \#157 and the AICPA audit guide. You do not have to revise the client's statement (Exhibit A); merely, describe what is wrong with the client's statement and also what information determined from your analysis should appear in other statements.

Exhibit A

\section{HOLLYBUSH ACADEMY \\ BALANCE SHEETS \\ JUNE 30, 2007 AND 2006}

\begin{tabular}{|c|c|c|c|c|}
\hline Assets & \multicolumn{2}{|r|}{2007} & \multicolumn{2}{|r|}{2006} \\
\hline Cash & $\$$ & 690,200 & $\$$ & 576,300 \\
\hline Cash equivalents & & $1,000,000$ & & $1,000,000$ \\
\hline Tuition receivable & & 173,100 & & 152,500 \\
\hline Other receivables & & 258,600 & & 278,900 \\
\hline Inventories & & 97,000 & & 97,000 \\
\hline Prepaid expenses & & 20,900 & & 18,800 \\
\hline Investment securities & & $22,222,100$ & & $20,747,700$ \\
\hline Premises and equipment & & $14,523,700$ & & $14,884,100$ \\
\hline Total Assets & $\$$ & $38,985,600$ & $\$$ & $37,755,300$ \\
\hline \multicolumn{5}{|l|}{ Liabilities and Fund Balances } \\
\hline \multicolumn{5}{|l|}{ Liabilities-- } \\
\hline Accounts payable & $\$$ & 122,300 & $\$$ & 137,400 \\
\hline Other liabilities & & 17,500 & & 12,700 \\
\hline Total Liabilities & & 139,800 & & 150,100 \\
\hline \multicolumn{5}{|l|}{ Fund Balances-- } \\
\hline Operating & & $2,100,000$ & & $1,973,400$ \\
\hline Plant & & $14,523,700$ & & $14,884,100$ \\
\hline Endowment & & $22,222,100$ & & $20,747,700$ \\
\hline Total Net Assets & & $38,845,800$ & & $37,605,200$ \\
\hline Total Liabilities and Net Assets & $\$$ & $38,985,600$ & $\$$ & $37,755,300$ \\
\hline
\end{tabular}




\section{TEACHING NOTES}

The best way for students to start this case is to ask three basic questions, namely:

1. What is wrong with the comparative financial statement prepared by the client?

2. Why was emphasis placed on FAS \#116, \#117, \#157 and the AICPA Audit and Accounting Guide, Not-forProfit Organizations?

3. How does one ensure that most of the relevant points are addressed?

The students should familiarize themselves with the main items addressed in FAS \#116, \#117, and \#157. They should discover that the financial statement prepared by the client was deficient because it addressed the statement as balance sheet instead of statement of financial position. Secondly, it was prepared using a fund balance approach instead of the recommended net assets (unrestricted, temporarily restricted, and permanently restricted).

If the students then follow the footnotes and the other audit findings point by point, they could list the deficiencies and cross-referenced them to the applicable areas in accounting literature. For example-

Note 1 -- Organization

Note 2 -- Summary of Significant Accounting Policies

Note 3 -- Promises to Give Receivable
Full Disclosure Principle and

APB \#22 -- "Disclosure of Accounting Policies"

Companies should disclose information about accounting policies and include those that users of financial statements find essential in order to make economic decisions.

Some students will cross reference specific policies to particular pronouncements. For example, concentration of credit risks was included in response to FAS \#107, "Disclosures About Fair Values of Financial Statements".

In addition, reasons for disclosures about volunteers and advertising costs could be found in the AICPA Audit and Accounting Guide.

After reading FAS \#116, students should find that promises to give (pledges) if in writing, must be recorded as a receivable at the net present value. Thus they should indicate that this item belongs on the Statement of Financial Position as an asset at net promises to give. They will also find out and indicate that if this were the first year of the campaign, contributions would be recorded at $\$ 5,060,400$ in the Statement of Activities. If the organization had promises to give in the prior year, the change would be debited or credited in the contributions line in the Statement of Activities. 
Note 4 -- Investment Securities

Note 5 -- Beneficial Interest in Charitable Trusts

Note 6 -- Bequest Receivable

Note 7 -- Premises and Equipment

Note 8 -- Accrued Severance Benefits

Note 9 -- Contingencies
Assuming that these are trading securities, they should be reported at fair value in the Statement of Financial Position and Unrealized Gains/Losses should be reported in the Statement of Activities along with Interest and Dividends and Realized Gains/Losses. Students should cite FAS \#115, "Accounting for Certain Investments in Debt and Equity Securities" and FAS \#157, "Fair Value Measurement. The client erroneously recorded these investments at cost.

Students should find information about split-interest agreements in the AICPA Accounting and Audit Guide. Research would reveal that this amount should be included in the Statement of Financial Position as an asset at its net present value. The change between years should be reflected in the Statement of Activities as Change in Beneficial Interest in Charitable Trusts as a revenue item. The client did not include this item on its financial statement.

Likewise the client did not include this item on its financial statement. Research in the AICPA Accounting and Audit Guide will reveal that it is a proper receivable assuming the wills have been probated.

Students could simply mention "historical cost principle" and "full disclosure principle". In addition, they could possibly refer to APB \#12 - "Omnibus Opinion-1967", which stated that companies should disclose the average useful life of the property and corresponding depreciation.

This item did not appear on the financial statement prepared by the client. However, an expense of $\$ 581,400$ should appear in the Statement of Activities with a corresponding liability in the Statement of Financial Position. This is a long-term liability and, accordingly, should be recorded as its net present value. It is based on services rendered prior to June 30, 2007 and thus is an expense of that period. Student should reference FAS \#106, 'Employers Accounting for PostRetirement Benefits Other Than Pensions".

Students could possibly cite FAS \#5, "Accounting for Contingencies". 
Other Audit Findings

Tuition receivable

Promises to Give Receivable

Inventories

Investment Securities

Beneficial Interest in Charitable Trusts

Accrued Salaries

Accrued Severance Pay

Unearned Income

Net Assets
The auditors found that the school was employing the direct write-off method to account for bad debts. It should be pointed out that this is not GAAP. Accordingly, a reserve of $\$ 63,000$ should be established with a corresponding bad debts expense of $\$ 63,000$.

FAS \#116 would reveal that this is a temporarily restricted asset as it has a donor imposed restriction that is only satisfied by the passage of time. Therefore, this amount should be reflected in net assets as part of temporarily restricted net assets.

The school should take an actual count of its bookstore and cafeteria inventory at the end of the year and reflect the appropriate cost on the Statement of Financial Position.

This should be stated at fair values as explained above.

This was explained above. The difference the asset at June 30, 2007 and the amount at June 30, 2006 should be reflected in the Statement of Activities as "Change in Beneficial Interest in Charitable Trusts". This could either be a revenue or expense depending on whether it was an increase or decrease from year to year.

The client has no amount for accrued salaries on the financial statement that it prepared. There should be an accrual for $\$ 420,000$ and $\$ 404,000$, respectively, at June 30, 2007 and 2006.

This was explained above.

These amounts were incorrectly recorded by the client. They employed the cash rather than accrual method of accounting. Therefore, $\$ 490,000$ and $\$ 380,000$, respectively should be included as unearned tuition at June 30, 2007 and 2006.

The client broke down its fund balances between operating, plant and endowment. According to FAS \#117, the proper categories are unrestricted, temporarily restricted, and permanently restricted net assets. 